\title{
Sealing type effect on corn silage quality in bunker silos
}

\author{
Mikael Neumann ${ }^{1}$ Guilherme Fernando Mattos Leão ${ }^{2}$ Eloize Jaqueline Askel $^{3}$ Fabiano Marafon $^{4}$ \\ Danúbia Nogueira Figueira ${ }^{5}$ Mailson Poczynek $^{6}$
}

\footnotetext{
${ }^{1}$ Departamento de Medicina Veterinária, Universidade Estadual do Centro Oeste (UNICENTRO), Guarapuava, PR, Brasil. E-mail: neumann.mikael@hotmail.com. "Corresponding author.

${ }^{2}$ Departamento de Zootecnia, Universidade Federal do Paraná (UFPR), Curitiba, PR, Brasil.

${ }^{3}$ Departamento de Medicina Veterinária, Universidade Estadual do Centro Oeste (UNICENTRO), Guarapuava, PR, Brasil.

${ }^{4}$ Departamento de Medicina Veterinária, Universidade Estadual do Centro Oeste (UNICENTRO), Guarapuava, PR, Brasil.

${ }^{5}$ Departamento de Zootecnia, Universidade Estadual Paulista "Júlio de Mesquita Filho", Jaboticabal, SP, Brasil.

${ }^{6}$ Departamento de Medicina Veterinária, Universidade Estadual do Centro Oeste (UNICENTRO), Guarapuava, PR, Brasil.
}

\begin{abstract}
Forage conservation in silos depends on the efficiency of silo sealing, among other factors, to minimize aerobic deterioration and consequent qualitative and quantitative losses in silage. Thus, the aim of the present study was to evaluate the effect of two sealing types on dry matter recovery rate, aerobic stability, nutritional composition, and in vitro digestibility of corn silage in bunker silos: 110- $\mu m-$ thick

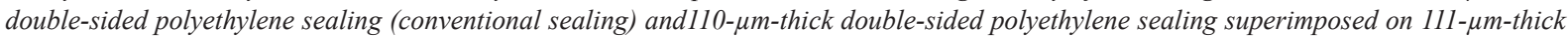
translucent polyethylene sealing (double sealing). There were no significant differences in nutritional composition of silages between conventional and double sealing. However, the double sealing system was more efficient $(P<0.05)$ in maintaining lower silo temperatures $\left(30.48^{\circ} \mathrm{C}\right.$ vs. $\left.31.18^{\circ} \mathrm{C}\right)$, in dry matter recovery $(88.79 \%$ vs. $85.64 \%)$, and increased in vitro neutral-detergent fiber digestibility (33.04\% vs. $\left.24.6 \%\right)$, when compared to the conventional version.
\end{abstract}

Keywords: neutral-detergent fiber digestibility, aerobic deterioration, dry matter recovery, temperature.

Eficiência do tipo de vedação sobre a qualidade de silagem de milho em silo trincheira

RESUMO: A conservação de forragens na forma de silagem depende, dentre outros fatores, da vedação eficiente do silo, com vistas a minimizar a deterioração aeróbia e consequentes perdas qualitativas e quantitativas da silagem. Assim, objetivou-se no presente trabalho, avaliar o efeito de dois tipos de vedação sobre o indice de recuperação de matéria seca, a estabilidade aeróbia, a composição nutricional e a digestibilidade "in vitro", em silos trincheira de armazenamento de silagem de milho: Vedação Convencional - polietileno tipo dupla face com espessura de $110 \mu \mathrm{m}$ e Dupla Vedação - polietileno tipo dupla face com espessura de $110 \mu \mathrm{m}$ sobreposto a outro polietileno translúcido com espessura de $111 \mu \mathrm{m}$. Não houve diferença significativa na composição nutricional das silagens resultantes entre os dois tipos de vedação, porém o sistema de dupla vedação foi mais eficiente $(P<0,05)$ na manutenção de menores temperaturas no interior do silo $\left(30,48^{\circ} \mathrm{C} v s 31,18^{\circ} \mathrm{C}\right)$, na recuperação da matéria seca $(88,79 \%$ vs $85,64 \%)$ e no aumento da digestibilidade "in vitro" da FDN (33,04\% vs $24,6 \%)$ quando comparado ao sistema de vedação convencional.

Palavras-chave: digestibilidade da FDN, deterioração aeróbica, recuperação de matéria seca, temperatura.

\section{INTRODUCTION}

The nutritional composition of corn silage determines particularities of its use in diet formulation for ruminant production systems. This composition depends on intrinsic factors of the crop and/or plant, such as hybrid characteristics, sowing density, fertilization level, growth rate, moisture degree, and physiological maturity at harvest. Moreover, characteristics related to the ensilage process are also important, such as particle size, specific storage mass and type of silage sealing material (BORREANI et al., 2007; SILVA et al., 2015), besides silage filling time, grain processing efficiency, process hygiene and fermentation time (NEUMANN et al., 2014).
Preservation of silage forage quality, both at storage and during use periods, depends on the anaerobiosis degree reached inside the sealed silo. Lateral and upper portions of bunker silos are more vulnerable to deterioration due to increased aerobic exposure and external temperature variations, and when sealing is inadequate and thin or present perforations and poor polyethylene quality (BORREANI et al., 2007).

Low efficiency in silo sealing triggers anaerobic and aerobic environment disturbances, leading to decreased aerobic stability due to changes in $\mathrm{pH}$ and temperature after silo opening and silage nutritional composition losses due to soluble carbohydrates spoliation by aerobic 
microorganisms, with energy production in the form of heat. Therefore, dry matter (DM) and fiber digestibility tends to decrease with increasing spoliation levels (FERRARETTO \& SHAVER, 2015; NEUMANN et al., 2014).

To reduce the deterioration process, oxygen penetration and temperature oscillations in silage mass must be reduced during storage and silos unload. Such goal can be achieved with plastic tarpaulins of high oxygen impermeability, refractoriness to solar rays, and good mechanical properties, and with double sealing systems, in which other polyethylene types actas oxygen barriers (BORREANI et al., 2007; BORREANI \& TABACCO, 2014; SILVA et al., 2015). Few published studies have tested the effect of double sealing on bunker silos.

In this context, the objective of this study was to evaluate the effect of two sealing types on DM recovery index, aerobic stability, nutritional composition, and digestibility of corn silages in bunker silos.

\section{MATERIALS AND METHODS}

The experiment was carried out in the Animal Production Center (Nupran, Núcleo de Produção Animal), for the Master's Degree Program in Agronomy, Department of Agrarian and Environmental Sciences of the Universidade Estadual do Centro-Oeste (Unicentro) located in the city of Guarapuava, State of Paraná (PR), Brazil.

The region of Guarapuava, Paraná is classified a sCfb (subtropical humid mesothermal climate), without a dry season, with fresh summer and moderate winter, according to Köppen classification. Its approximate altitude is $1,100 \mathrm{~m}$, average annual rain fall of $1,944 \mathrm{~mm}$, average annual temperature of $12.7^{\circ} \mathrm{C}$ (min.) and $23.5^{\circ} \mathrm{C}$ (max.), and $77.9 \%$ relative humidity (IAPAR, 2000).

The soil of the study area is classified as typical haplohumox and presented the following chemical characteristics in its $0-20 \mathrm{~cm}$ profile, before planting: $\mathrm{pH} \mathrm{CaCl} 20.01 \mathrm{M}: 4.7 ; \mathrm{P}: 1.1 \mathrm{mg} \mathrm{dm}^{3} ; \mathrm{K}^{+} 0.2 \mathrm{cmol}_{\mathrm{c}} \mathrm{dm}^{-3}$; Mo: $2.62 \% ; \mathrm{Al}^{3+}: 0.0 \mathrm{cmol}_{\mathrm{c}} \mathrm{dm}^{-3} ; \mathrm{H}^{+}+\mathrm{Al}^{3+}: 5.2 \mathrm{cmol} \mathrm{dm}^{-3}$; $\mathrm{Ca}^{2+} 5.0 \mathrm{cmol}_{\mathrm{c}} \mathrm{dm}^{3} ; \quad \mathrm{Mg}^{{ }^{2}}: 5.0 \mathrm{cmol}_{\mathrm{c}} \mathrm{dm}^{-3} ; \quad$ and base saturation: $67.3 \%$.

The study objective was to evaluate the effect of two sealing types on the DM recovery rate, aerobic stability, nutritional composition, and in vitro digestibility of corn silage in bunker silos: 110- $\mu \mathrm{m}$-thick double-sided polyethylene sealing (conventional sealing) and $110-\mu \mathrm{m}$-thick double-sided polyethylene sealing superimposed on 111- $\mu \mathrm{m}$-thick translucent polyethylene sealing (double sealing).

The evaluated silage was produced from a two-hectare area, using the SG-6418 hybrid type. For crop establishment, line spacing was $0.80 \mathrm{~m}$, sowing depth was $0.04 \mathrm{~m}$, and the distribution was 4.4 plants $\mathrm{m}$ linear ${ }^{1}$, totaling a final harvest population of 53,625 plants $\mathrm{ha}^{-1}$. The 08-30-20 compound $\left(\mathrm{N}-\mathrm{P}_{2} \mathrm{O}_{5}-\mathrm{K}_{2} \mathrm{O}\right)$ was used as base fertilizer (400kg ha ${ }^{-1}$ ), according to the Fertilization and Liming Guidelines for the states of Rio Grande do Sul and Santa Catarina (CFS-RS/SC, 2004).

During the first 30 days after emergence, plants were treated with herbicide (commercial product: Atrasina, 4L ha ${ }^{-1}$ ) plus mineral oil (commercial product: Assit, 1L ha ${ }^{-1}$ ) and defensive for armyworm control (commercial product: Karate; $150 \mathrm{ml} \mathrm{ha}^{-1}$ ), according to the crop technical report. Cover fertilization was conducted with nitrogen (125 $\mathrm{kg} \mathrm{N} \mathrm{ha}{ }^{-1}$ ) in urea form (46-00-00), applied when plants had four to six totally expanded leaves.

Crops were harvested at chalky grain phenological stage, using a Nogueira ${ }^{\circledR}$ silage filler adjusted to the particle size and plant cutting height of $20 \mathrm{~cm}$. The particle size analysis showed $11.56 \%$ proportion in the first sieve $(>19 \mathrm{~mm}), 47.60 \%$ in the second sieve $(8-19 \mathrm{~mm})$, and $40.85 \%$ in the third sieve $(<8 \mathrm{~mm})$. The harvested material was transported and stored in eight horizontal bunker silos placed in a leveled and well-drained location, with $1.5 \mathrm{~m}$ wide $\times 1.0 \mathrm{~m}$ high $\times 10 \mathrm{~m}$ long concrete walls and floors. The material was compacted using a tractor and later completely sealed and protected according to the study factor. Filling and closing time for each silo ranged from 6-8 hours.

After the silos were opened, 120 days after they were produced, silage was continuously used to feed animals, respecting the daily silage extraction slice of $15 \mathrm{~cm}$ for eight consecutive weeks for each silo.

The recovery index of DM was obtained according tomethod developed by NEUMANN et al. (2007), using eight bags placed in each experimental silo, in its lower and upper portions, whose weights and DM were measured before and after the ensiling process. Bags were composed of $100 \%$ polyamine malleable nylon containing $85-\mu$ mpores, $12 \mathrm{~cm}$ in diameter and $50 \mathrm{~cm}$ in length, with the average capacity of 2,000g.

During the desensilation periods that occurred daily at 7:30a.m. and 4:30p.m., silage $\mathrm{pH}$ and temperature $\left({ }^{\circ} \mathrm{C}\right)$ were determined, using silage samples from lower and upper strata of the silos facial panel. Temperature $\left({ }^{\circ} \mathrm{C}\right)$ was determined using a metal 
rod digital thermometer, timer, and current amplitude reading of -50 to $250^{\circ} \mathrm{C}$, in both external and silage environments, in abovementioned strata, $7 \mathrm{~cm}$ deep, in the structured mass on silo face. The $\mathrm{pH}$ readings were performed using a digital potentiometer, according to the methodology established by CHERNEY \& CHERNEY (2003).

Homogeneous silage samples from lower and upper strata of silo panel were collected weekly, weighed, and pre-dried in a forced air oven at $50^{\circ} \mathrm{C}$ until reaching aconstant weight for DM content determination, according to SILVA \& QUEIROZ (2009). The samples were sequentially milled in a Willey-type mill using 1-mm sieve mesh.

The following variables were determined in the milled samples: total $\mathrm{DM}$ in oven at $105^{\circ} \mathrm{C}$, gross protein (GP) through the micro Kjeldahl method, ethereal extract (EE), and mineral matter (MM) according to SILVA \& QUEIROZ (2009). The contents of neutral-detergent fiber (NDF) obtained using thermostable $\alpha$-amylase (Termamyl 120L, Novozymes Latin America Ltda.) according to Van SOEST et al. (1991) and acid-detergent fiber content (ADF) obtained according to GOERING \& Van SOEST (1970) were also determined. The hemicellulose values were estimated by the difference between NDF and ADF, according to SILVA \& QUEIROZ (2009). Calcium and phosphorus contents were determined according to TEDESCO et al. (1995). In vitro digestibility of both DM and NDF were evaluated according to TILLEY \& TERRY (1963).

The study design was completely randomized, consisting of two treatments with four replications each, where each replicate consisted of one silo. Data collected for each variable were submitted to analysis of variance with Tukey's test, at 5\% significance, using SAS statistical software (1993).

\section{RESULTS AND DISCUSSION}

Table 1 shows the average values of $\mathrm{DM}$ recovery index, temperature, $\mathrm{pH}$ and $\mathrm{DM}$ of silage from the lower and upper strata of facial silo, according to time of data collection (morning or afternoon) and sealing type.

Double sealing presented $3.67 \%$ higher DM recovery rate (overall average) than the conventional sealing $(88.79 \%$ vs $85.64 \%)$, leading to lower losses during the fermentation process, lower ensilage costs, and higher final volume of available food. One possible justification for this result is the better efficiency of double sealing in avoiding oxygen infiltration in the ensiled material.
Of note, the difference between treatments observed in this parameter occurred in the upper stratum, where the double sealing was $7.54 \%$ greater than the conventional sealing.

Similarly, BORREANI \& TABACCO (2014) observed higher DM recovery rates for doublesealed silos when compared to the conventional version $(94.15 \%$ vs $77.95 \%)$, with most central silo areas $17.2 \%$ higher in this parameter in relation to the upper and lateral portions. BERNARDES et al. (2011), when evaluating doubled-sealed silos with polyethylene and polyamide tarpaulins (of high oxygen impermeability) and conventional sealed silos (of simple double-sided tarpaulin), observed losses in upper silo layers of 8.2 and $13.8 \%$, respectively. In these systems, DM losses were highly correlated with tarpaulin oxygen permeability. In the present study, losses in DM were 14.36 and $11.21 \%$ for conventional and double sealing, respectively.

BORREANI et al. (2007) compared different types of polyethylene and verified that DM losses were 3.7 times higher in the upper portion of conventionally sealed silos in relation to doubledsealed silos, suggesting the influence of plastic film on DM recovery index.

Therefore, the use of plastic tarpaulin double sealed systems in relation to the conventional sealing favors anaerobic storage conditions, which results in proper conditions for the preservation and conservation of silage quality, especially in regions that are susceptible to losses, like the upper silos portion (BERNARDES et al., 2011).

In addition to these advantages, BORREANI \& TABACCO (2014) reported that the use of double sealing was associated with smaller quantities of discarded silage due to lower losses, thus requiring less labor. In this sense, despite the higher cost, the net economic benefit was evident in properties in which such silo cover was used.

Regarding the temperature analysis (Table 1), on average, the conventional sealing promoted higher temperatures $(\mathrm{P}<0.05)$, of approximately $2.29 \%$ in relation to the double sealing, regardless of silo portion and period of the day.

According to JUNGA \& TRÁVNICEK (2015), temperature increases in the ensiled mass are indicative of aerobic deterioration. They suggest the heat increase inside the silo originates from soluble carbohydrates and lactic acid degradation by yeasts and filamentous fungi. These organisms act in the presence of oxygen, resulting in lower DM recovery, higher $\mathrm{pH}$ and lower nutritional value. 
Table 1 - Average values of DM recovery index, temperature, $\mathrm{pH}$ and DM content of silage from silo face upper and lower strata, associated with period of the day (morning or afternoon), according to the sealing type used in the storage silo.

\begin{tabular}{|c|c|c|c|c|c|c|}
\hline \multirow{2}{*}{ Silo face } & \multirow{2}{*}{ Period of the day } & \multicolumn{2}{|c|}{ 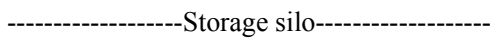 } & \multirow[t]{2}{*}{ Average } & \multirow[t]{2}{*}{$\mathrm{CV}(\%)$} & \multirow[t]{2}{*}{$\mathrm{P}>\mathrm{F}$} \\
\hline & & Conventional sealing & Double sealing & & & \\
\hline & & -DM recovery & lex (\%)---------. & -------------- & ----------- & -------- \\
\hline Upper stratum & - & $82.72^{\mathrm{b}}$ & $88.96^{\mathrm{a}}$ & 85.84 & 2.84 & 0.0102 \\
\hline Lower stratum & - & 88.57 & 88.62 & 88.60 & 1.27 & 0.9495 \\
\hline Overall average & - & 85.64 & 88.79 & 87.21 & 2.17 & 0.0161 \\
\hline \multicolumn{7}{|c|}{ 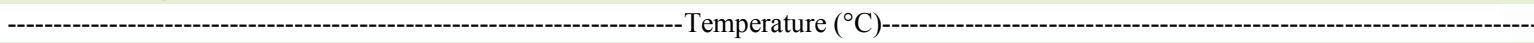 } \\
\hline Upper stratum & Morning & 31.96 & 31.64 & 31.80 & 5.80 & 0.4961 \\
\hline Lower stratum & Morning & 26.86 & 26.38 & 26.62 & 5.77 & 0.2098 \\
\hline Upper stratum & Afternoon & 35.97 & 34.95 & 35.46 & 6.68 & 0.0912 \\
\hline Lower stratum & Afternoon & 29.62 & 29.09 & 29.36 & 6.04 & 0.2449 \\
\hline Overall average & - & 31.18 & 30.48 & 30.83 & 1.38 & 0.0001 \\
\hline \multicolumn{7}{|c|}{ 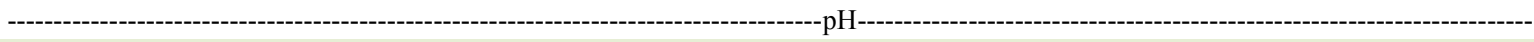 } \\
\hline Upper stratum & - & 3.73 & 3.75 & 3.74 & 2.62 & 0.5121 \\
\hline Lower stratum & - & $3.76^{\mathrm{a}}$ & $3.69^{\mathrm{b}}$ & 3.72 & 2.82 & 0.0094 \\
\hline Overall average & - & 3.75 & 3.72 & 3.73 & 2.73 & 0.1324 \\
\hline \multicolumn{7}{|c|}{ 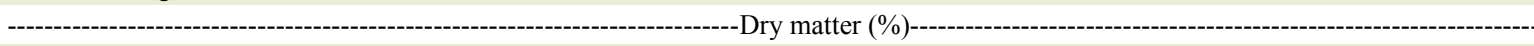 } \\
\hline Upper stratum & - & 32.66 & 31.85 & 32.26 & 2.26 & 0.2149 \\
\hline Lower stratum & - & 32.83 & 31.71 & 32.27 & 2.52 & 0.1467 \\
\hline Overall average & - & 32.74 & 31.78 & 32.26 & 2.24 & 0.0324 \\
\hline
\end{tabular}

Averages followed by different letters in the line differ $(\mathrm{P}<0.05)$ from each other by $\mathrm{F}$ test.

BORREANI \& TABACCO (2010) evaluated 54 dairy farms and observed variations in silo temperature. A reference temperature of silos was measured in their central portion, and differences between that and temperatures measured in peripheral and moldy spots areas were related to aerobic deterioration. This process was positively correlated with $\mathrm{pH}$ increase; water activity; filamentous fungi, yeast and clostridial spores count; and negatively correlated with the presence of lactic and acetic acid, and nitrate concentration.

Lower stratum from conventionally sealed silos presented higher $\mathrm{pH}(\mathrm{P}<0.05)$, when compared to double sealing (3.76 vs 3.69). However, neither the upper stratum nor the average $\mathrm{pH}$ was significantly different between the groups.

McGECHAN \& WILLIANS (1994) proposed a model in which oxygen enters the silo through a pressure difference mechanism and is spread inside the silo by diffusion. Thus, this higher $\mathrm{pH}$ observed in conventionally sealed silo may result from greater oxygen infiltration due to greater tarpaulin permeability. It may have allowed the activity of microorganisms, such as yeasts and filamentous fungi, causing the abovementioned spoliation activity, with effect on $\mathrm{pH}$ elevation
(GALLO et al., 2015). There was no difference in $\mathrm{pH}$, temperature, and $\mathrm{DM}$ content in relation to the period of silage use when comparing both sealing types (Figure 1).

Table 2 shows these aling type did not affect corn silage nutritional composition $(\mathrm{P}>0.05)$, except for NDF digestibility. A different result was reported by BORREANI \& TABACCO (2014), who evaluated two sealing types in two commercial properties and observed the average proportions of NDF, ADF, GP, and $\mathrm{MM}$ were respectively $11.6 \%, 21.9 \%, 25.9 \%$, and $32.9 \%$ lower in double-sealed silos.

According to ROOKE \& HATFIELD (2003), the greater participation of fibrous carbohydrates in the abovementioned study was due to the activity of yeasts and filamentous fungi. These organisms degrade non-fibrous carbohydrates, generating a fibrous carbohydrates increase as a result of the concentration effect.

Nevertheless, the most expressive result obtained in this study and that shows the great influence of this system, was the NDF digestibility, which was $25.54 \%$ higher $(\mathrm{P}<0.05)$ in double sealing system, demonstrating its importance for the production of high quality silage. BERNARDES et al. (2011) also observed a $6 \%$ decrease of NDF 


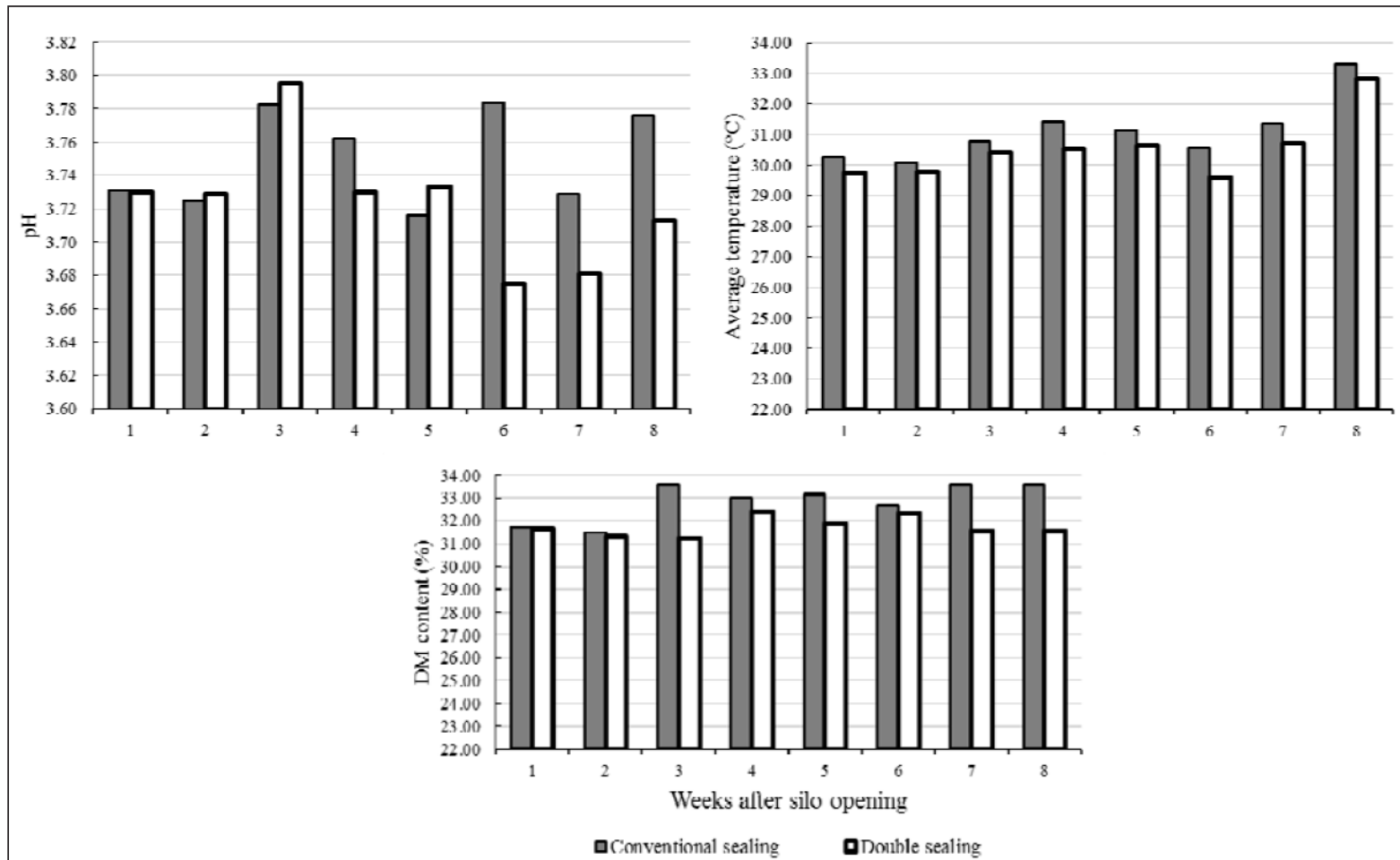

Figure 1 - Average weekly temperature, dry matter content and silo panel $\mathrm{pH}$ values, according to the sealing type used in the storage silo.

proportion associated with the use of double sealing with high oxygen impermeability, when compared to the conventional sealing.

Corn silages with more digestible fiber imply higher DM consumption, as it reduces the filling effect. In addition, increasing the energy of this material would reduce variable property costs due to the lower participation of concentrate in the diet and it could ensure ruminant health due to the greater frequency of rumination, which implies greater ruminal buffer, higher milk fat production and extended animal production, provided that particle size is respected (FERRARETTO \& SHAVER, 2015).

Table 2 - Chemical and nutritional composition of the corn silage, according to the sealing type used in the storage silo.

\begin{tabular}{|c|c|c|c|c|c|}
\hline \multirow{2}{*}{ Nutritional composition } & \multicolumn{3}{|c|}{ 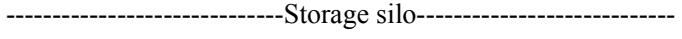 } & \multirow{2}{*}{ CV $(\%)$} & \multirow{2}{*}{$\mathrm{P}>\mathrm{F}$} \\
\hline & Conventional sealing & Double sealing & Average & & \\
\hline Dry matter, \% & 30.49 & 30.91 & 30.70 & 2.71 & 0.3503 \\
\hline Crude protein, $\%$ of DM & 6.30 & 6.20 & 6.25 & 6.20 & 0.6253 \\
\hline Ethereal extract, \% in DM & 2.81 & 2.76 & 2.78 & 8.86 & 0.4767 \\
\hline Neutral detergent fiber, $\%$ of DM & 46.03 & 47.10 & 46.56 & 11.54 & 0.7035 \\
\hline Hemicellulose, $\%$ of DM & 19.06 & 19.07 & 19.06 & 9.12 & 0.9978 \\
\hline Acid detergent fiber, $\%$ of DM & 26.97 & 28.03 & 27.50 & 13.32 & 0.5798 \\
\hline Mineral matter, $\%$ of DM & 3.56 & 4.13 & 3.84 & 26.86 & 0.3059 \\
\hline Calcium, $\%$ of DM & 0.16 & 0.19 & 0.17 & 30.66 & 0.2534 \\
\hline Phosphorus, $\%$ of DM & 0.16 & 0.18 & 0.17 & 26.03 & 0.3868 \\
\hline DM digestibility, $\%$ & 75.46 & 74.46 & 74.96 & 2.59 & 0.2335 \\
\hline NDF digestibility, $\%$ & $24.60^{\mathrm{b}}$ & $33.04^{\mathrm{a}}$ & 28.82 & 23.22 & 0.0104 \\
\hline
\end{tabular}

Averages followed by different letters in the line differ $(\mathrm{P}<0.05)$ from each other by $\mathrm{F}$ test. 


\section{CONCLUSION}

The use of polyethylene double sealing systems in bunker silos is recommended to determine higher NDF digestibility, reduction of DM losses, and greater silage aerobic stability.

\section{REFERENCES}

BERNARDES, T.F. et al. Top spoilage losses in maize silage sealed with plastic films with different permeabilities to oxygen. Grass and Forage Science, v.67, p.34-42, 2011. Available from: $<$ http:// onlinelibrary.wiley.com/doi/10.1111/j.1365-2494.2011.00823.x/ epdf?r3_referer=wol\&tracking_action $=$ preview_click\&show checkout $=1 \&$ purchase referrer $=w w w . g o o g l e . c o m . b r \& p u r c h a s e$ site_license=LICENSE_DENIED $>$. Accessed: Feb. 17, 2016. doi: 10.1111/j.1365-2494.2011.00823.x.

BORREANI, G.; TABACCO, E. Improving corn silage quality in the top layer of farm bunker silos through the use of a nextgeneration barrier film with high impermeability to oxygen. Journal Dairy Science, v.97, p.2415-2426, 2014. Available from: $<$ http://dx.doi.org/10.3168/jds.2013-7632>. Accessed: Feb. 2, 2016. doi: 10.3168/jds.2013-7632.

BORREANI, G.; TABACCO, E. The relationship of silage temperature with the microbiological status of the face of corn silage bunkers. Journal Dairy Science, v.93, p.2620-2629, 2010. Available from: <J.DairySci.93:2620-2629doi:10.3168/jds.20092919>. Accessed: Feb. 2, 2016. doi: 10.3168/jds.2009-2919.

BORREANI, G. et al. A new oxygen barrier film reduces aerobic deterioration in farm-scale corn silage. Journal of Dairy Science, v.90, p.4701-4706, 2007. Available from: <J.DairySci.90:47014706doi:10.3168/jds.2007-0310>. Accessed: Feb. 2, 2016. doi: $10.3168 /$ jds.2007-0310.

CHERNEY, J.H.; CHERNEY, D.J.R. Assessing silage quality. In: BUXTON, D.R. et al. Silage science and technology. Madison: American Society of Agronomy, Crop Science Society of America, Soil Science of America, 2003. p.141-198.

COMISSÃO DE QUÍMICA E FERTILIDADE DO SOLO (CFSRS/SC). Manual de adubação e calagem para os Estados do Rio Grande do Sul e de Santa Catarina. 10.ed. Porto Alegre, SBCS - Núcleo Regional Sul/UFRGS, 2004. 400p.

FERRARETTO, L.F.; SHAVER R.D. Effects of whole-plant corn silage hybrid type on intake, digestion, ruminal fermentation, and lactation performance by dairy cows through a meta-analysis.Journal of Dairy Science, v.98, n.4, p.2662-2675, 2015. Available from: $<$ J. Dairy Sci. 98 :2662-2675 http://dx.doi.org/ 10.3168/jds.2014-9045>. Accessed: Feb. 27, 2016. doi: 10.3168/jds.2014-9045.

GALLO, A. et al. Review on mycotoxin issues in ruminants: occurrence in forages, effects of mycotoxin ingestion on health status and animal performance and practical strategies to counteract their negative effects. Toxins, v.7, p.3057-3111, 2015. Available from: <www.mdpi.com/20726651/7/8/3057>. Accessed: Feb. 2, 2016. doi: 10.3390/toxins7083057.
GOERING, H.K.; VAN SOEST, P.J. Forage fiber analysis: apparatus reagents, procedures and some applications. Washington, D.C.: Agricultural Handbook, 1970. 379p.

INSTITUTO AGRONÔMICO DO PARANÁ (IAPAR). Cartas climáticas do Paraná. Londrina, 2000. 1 CD.

JUNGA, P.; TRÁVNÍCEK, P. Surface temperature of the exposed silo face as quick indicator of the decomposition process of maize silage. Journal of Central European Agriculture, v.16, n.1, p.76-91, 2015. Available from: <https://jcea.agr.hr/volumes. php?search=Article\%3A1544>. Accessed: Feb. 2, 2016. doi: 10.5513/JCEA01/16.1.1544.

MCGECHAN, M.B.; WILLIAMS, A.G. A model of air infiltration losses during silage storage. Journal of Agricultural Engineering Research, v.57, n.4, p.237-249, 1994. Available from: <http:// www.sciencedirect.com/science/article/pii/S0021863484710249>. Accessed: Feb. 13, 2016. doi: 10.1006/jaer.1994.1924.

NEUMANN, $M$. et al. Ensilagem: estratégias visando maior produção de leite. In: SIMPÓSIO BRASILEIRO DE RUMINANTES LEITEIROS, 2014, Uberlândia, MG. Anais... Uberlandia: Universidade Federal de Uberlandia. p.130-166.

NEUMANN, M. et al. Effect of particle size and cutting height of corn (Zea mays L.) on losses of silages during the fermentation process and utilization period. Revista Brasileira de Zootecnia, v.36, n.5, p.1395-1405, 2007. Available from: <http://www.scielo. br/pdf/rbz/v36n5/24.pdf>. Accessed: Aug. 25, 2016. doi: 10.1590/ S1516-35982007000600024.

ROOKE, J.A; HATFIELD, R.D. Biochemistry of ensiling. In: BUXTON et. al. Silage science and technology. Madison: USDAARS, 2003. p.95-135.

SAS INSTITUTE. SAS/STAT user's guide: statistics, version 6 . 4.ed. North Caroline, 1993. V.2, 943p.

SILVA, D.J.; QUEIROZ, A.C. Análise de alimentos, métodos químicos e biológicos. 3.ed.Viçosa: UFV, 2009. 235p.

SILVA, M.S.J. et al. Production technology and quality of corn silage for feeding dairy cattle in Southern Brazil. Revista Brasileira de Zootecnia, v.44, n.9, p.303-313, 2015. Available from: < http:// www.scielo.br/pdf/rbz/v44n9/1516-3598-rbz-44-09-00303.pdf>. Accessed: Feb. 2, 2016. doi: 10.1590/S1806-92902015000900001.

TEDESCO, M.J. et al. Análises de solo, plantas e outros materiais. Porto Alegre: UFRGS, 1995. 174p. (Boletim técnico, 5).

TILLEY, J.M.A.; TERRY, R.A. A two-stage technique for the in vitro digestion of forage crops. Grass and Forage Science, v.18, p.104-111, 1963. Available from: <http://onlinelibrary.wiley.com/ doi/10.1111/j.1365-2494.1963.tb00335.x/pdf>. Accessed: Feb. 2, 2016. doi: 10.1111/j.1365-2494.1963.tb00335.x.

Van SOEST, P.J. et al. Methods for dietary fiber, neutral detergent fiber, and non starch polysaccharides in relation to animal nutrition. Journal of Dairy Science, v.74, p.3583-3597, 1991. Available from: ‘http://www.journalofdairyscience. org/article/S0022-0302(91)78551-2/pdf>. Accessed: Feb. 2, 2016. 